\title{
PENGARUH JOB INSECURITY, BUDAYA ORGANISASI, DAN LINGKUNGAN KERJA TERHADAP KOMITMEN ORGANISASIONAL
}

\author{
I Ketut Agus Pande Gunawan ${ }^{1}$ \\ I Komang Ardana ${ }^{2}$ \\ ${ }^{1,2}$ Fakultas Ekonomi dan Bisnis Universitas Udayana, Bali, Indonesia \\ email: aguspgunawan@yahoo.com
}

\begin{abstract}
ABSTRAK
Komitmen organisasional adalah sikap yang mencerminkan loyalitas karyawan terhadap organisasi, dan proses yang berkelanjutan di mana karyawan mengekspresikan kepedulian mereka terhadap organisasi, kesuksesan, dan kesejahtraan. Tujuan dari penelitian ini untuk menjelaskan pengaruh job insecurity, budaya organisasi, dan lingkungan kerja pada komitmen organisasional.Penelitian ini dilakukan pada Artha Agung Resort and Restaurant, J1. Raya Besakih, Menanga, Karangasem dengan pendekatan kuantitatif berbentuk asosiatif. Teknik sampel yang digunakan yaitu teknik sampel jenuh serta metode pengumpulan data menggunakan pendekatan survey dengan metode kuisioner yang diukur menggunakan skala likert. Sampel berjumlah 31 karyawan. Teknik analisis regresi linear berganda. Berdasarkan hasil penelitian ini menunjukkan bahwa job insecurity berpengaruh negatif signifikan terhadap komitmen organisasional, serta budaya organisasi, dan lingkungan kerja berpengaruh positif signifikan pada komitmen organisasional.

Kata Kunci : Ketidakamanan Kerja, Budaya Organisasi, Lingkungan Kerja, Komitmen Organisasional
\end{abstract}

\begin{abstract}
Organizational commitment is an attitude that reflects employee loyalty to the organization, and an ongoing process in which employees express their concern for the organization, success, and prosperity. The purpose of this study is to explain the effect of job insecurity, organizational culture, and work environment on organizational commitment. This research was conducted at Artha Agung Resort and Restaurant, Jl. Raya Besakih, Menanga, Karangasem with a quantitative approach in the form of associative. The sample technique used is the saturated sample technique and the data collection method using a survey approach with a questionnaire method that is measured using a Likert scale. A sample of 31 employees. Multiple linear regression analysis technique. Based on the results of this study indicate that job insecurity has a significant negative effect on organizational commitment, and organizational culture, and the work environment has a significant positive effect on organizational commitment.

Keywords: Work Insecurity, Organizational Culture, Work Environment, Organizational Commitment
\end{abstract}




\section{PENDAHULUAN}

Era globalisasi dan perdagangan bebas menuntut perusahaan-perusahaan untuk lebih kompetitif sehingga tujuan dapat dicapai secara maksimal. Selain melibatkan pemakaian teknologi yang moderen, perusahaan juga harus lebih memberi perhatian terhadap pengelolaan sumber daya menusia (SDM) secara lebih sungguh-sungguh.

Sumber daya manusia (SDM) perusahaan harus terus dikembangkan oleh perusahaan, pararel dengan perkembangan zaman, sehingga karyawan dapat bekerja secara lebih profesional, bertanggung jawab, disamping memiliki attitude yang baik dengan kata lain, agar tujuan dapat tercapai perusahaan membutuhkan karyawan yang berkomitmen tinggi.

Komitmen organisasional adalah sikap yang mencerminkan loyalitas karyawan terhadap organisasi mereka dan proses yang berkelanjutan di mana peserta organisasi mengekspresikan kepedulian mereka terhadap organisasi, kesuksesan, dan kesejahtraan (Luthans, 2005). Berdasarkan penelitian yang telah dilakukan dapat diketahui bahwa faktor yang dapat mempengaruhi komitmen organisasional adalah job insecurity. Septiari \& Ardana (2016) mengatakan bahwa job insecurity adalah kondisi pisikologis seorang karyawan yang merasa bingung dan tidak aman, karena adanya kondisi lingkungan yang berubah-ubah, yang dapat mengancam masa depannya. Oleh Kekesi \& Agyemang (2014) job insecurity dikatakan sebagai ketidakpastian dan kurangnya kontrol dari kelanjutan masa depan pekerjaan karyawan. Sverke et al. (2002) menemukan beberapa dampak job insecurity bagi karyawan dan organisasi. Jangka pendek job insecurity dapat berdampak terhadap komitmen organisasional, seperti kurangnya kepercayaan terhadap pimpinan. Jangka panjang job insecurity dapat berpengaruh terhadap kesehatan fisik, mental, performa kerja, dan munculnya intensi niat pindah kerja.

Penelitian terkait dengan job insecurity yang dilakukan oleh Yasmin (2011), menghasilkan bahwa job insecurity berpengaruh negatif terhadap komitmen organisasional pada karyawan PT. Asia Outsourcing Services yang ditempatkan di PT. X. Selain itu penelitian yang dilakukan oleh Pangat (2013) memperoleh hasil job insecurity berpengaruh negatif terhadap komitmen organisasional. Hasil dari penelitian Ezra et al. (2019) juga memperoleh hasil job insecurity berpengaruh negatif terhadap komitmen organisasional.

Pada sisi yang lain, Lok et al. (2004) mengemukakan bahwa budaya organisasi merupakan faktor yang sangat berpengaruh penting terhadap komitmen organisasional. Menurut Sanhaji (2016) budaya organisasi berpengaruh terhadap perilaku para anggota organisasi, karena sistem nilai dalam budaya organisasi dapat menjadi acuan bagi anggota organisasi dalam berperilaku. Purnamasari \& Sriathi (2018) memperkuat pendapat bahwa budaya yang kuat memiliki pengaruh kuat dalam pembentukan perilaku anggota organisasi. Semakin banyak anggota yang menerima nilai-nilai bersama tersebut, maka akan menimbulkan sense of belonging yang kemudian memupuk dapat komitmen mereka terhadap organisasi. Jadi dapat dikatakan budaya organisasi menjadi sesuatu hal yang penting untuk diperhatikan karena perannya dalam meningkatkan komitmen organisasional.

Penelitian mengenai budaya organisasi pada komitmen organisasional yang dilakukan oleh Khoiroh et al. (2018) menghasilkan bahwa budaya organisasi 
berpengaruh positif terhadap komitmen organisasional dalam Meningkatkan Kinerja Pegawai pada Badan Perencanaan Pembangunan Daerah (BAPPEDA) Kabupaten Batang Hari. Hasil penelitian oleh Reskantika et al. (2019) juga memperoleh hasil budaya organisasi berpengaruh positif dan signifikan terhadap komitmen organisasional. Hasil penelitian yang sama dilakukan oleh Faisal \& Dewi (2019) menghasilkan bahwa budaya organisasi berpengaruh positif terhadap komitmen organisasional karyawan, hal ini berarti perusahaan diharapkan agar mempertahankan budaya berupa norma-norma dan nilai-nilai yang diterapkan di perusahaan tetap terjaga sehingga dapat meningkatkan komitmen organisasional karyawan untuk tetap tinggal di perusahaan.

Selain job insecurity dan budaya organisasi komitmen dari peneliti yang dilakukan terdahulu juga dapat dipengaruhi oleh lingkungan tempat karyawan bekerja. Menurut Widodo (2014) lingkungan kerja merupakan sesuatu di luar organisasi yang berpotensi mempengaruhi karyawan dalam bekerja, dan pada akhirnya dapat berkontribusi terhadap kinerja organisasi. Selain itu Faisal \& Dewi (2019) meminta organisasi untuk bisa memberikan rasa nyaman dan aman bagi setiap karyawan di dalam melakukan pekerjaannya. Jika lingkungan kerja kurang menunjang, misalnya pada fasilitas teknologi, maupun dalam hal kenyamanan, hubungan kerja yang tidak harmonis, jaminan sosial dan keamanan yang kurang, maka terdapat kecenderungan komitmen karyawan terhadap organisasi menjadi makin luntur. Lingkungan kerja baik lingkungan fisik dan non fisik adalah bagian yang tidak kalah penting bagi keberlangsungan kerja karyawan dan masa depan organisasi.

Penelitian terkait lingkungan kerja yang dilakukan oleh Saputra \& Andri (2017) menghasilkan bahwa lingkungan kerja berpengaruh positif signifikan terhadap komitmen organisasional. Selain itu juga penelitian Herjany \& Bernarto (2018) dilakukan pada TK dan SD pada Sekolah X di Jakarta Barat menghasilkan bahwa lingkungan kerja berpengaruh positif terhadap komitmen organisasional. Hasil penelitian Faisal \& Dewi (2019) menghasilkan bahwa lingkungan kerja berpengaruh positif terhadap komitmen organisasional karyawan yang artinya semakin baik lingkungan kerja pada perusahaan, maka semakin tinggi komitmen karyawan untuk tetap berorganisasi di perusahaan.

Artha Agung Resort and Restaurant adalah salah satu resort dan restaurant yang berlokasi di Jl. Raya Besakih, Menanga, Karangasem. Resort dan Restaurant ini cukup strategis karena lokasinya itu dekat dengan Pura Besakih tidak sedikit wisatawan yang memilih resort dan restaurant ini sebagai tempat beristirahat. Artha Agung Resort and Restaurant agar tidak ditinggalkan oleh para tamu-tamu terus berikhtiar untuk meningkatkan kualitas pelayanan, terutama di bagian karyawannya, perusahaan terus berupaya untuk memperoleh karyawan yang memiliki komitmen organisasi yang kuat.

Komitmen diartikan sebagai tingkat kepercayaan dan penerimaan karyawan terhadap tujuan organisasi dan mempunyai keinginan untuk tetap ada di dalam organisasi. Angelia (2013) mengemukakan bahwa komitmen organisasi memiliki hubungan dengan tingkat kehadiran. Karyawan yang memiliki komitmen organisasi yang tinggi, akan lebih termotivasi untuk selalu hadir ke kantor membantu proses pencapaian tujuan dari organisasi. 
Karyawan yang kurang berkomitmen akan cenderung menarik diri dari organisasinya melalui ketidakhadiran, sebaliknya anggota yang memiliki komitmen yang tinggi pada organisasi akan memberikan sumbangan terhadap organisasi dalam hal stabilitas tenaga kerja (Nofriansyah, 2017). Dari observasi yang dilakukan pada Artha Agung Resort and Restaurant diperoleh data tentang tingkat kehadiran karyawan seperti yang ditunjukkan pada Tabel 1.

Tabel 1.

Absensi Karyawan pada Artha Agung Resort and Restaurant 2019

\begin{tabular}{|c|c|c|c|c|c|c|c|}
\hline No & Bulan & $\begin{array}{c}\text { Jumlah } \\
\text { Karyawan } \\
\text { (orang) }\end{array}$ & $\begin{array}{c}\text { Jumlah } \\
\text { Hari } \\
\text { Kerja } \\
\text { Per } \\
\text { Bulan } \\
\text { (hari) } \\
(2)\end{array}$ & $\begin{array}{c}\text { Jumlah } \\
\text { Hari } \\
\text { Kerja } \\
\text { Seharusn } \\
\text { ya (hari) } \\
(1 \times 2)=(3)\end{array}$ & $\begin{array}{c}\text { Jumlah } \\
\text { Absensi } \\
\text { Per } \\
\text { Bulan } \\
\text { (hari) } \\
\\
(4)\end{array}$ & $\begin{array}{c}\text { Jumlah } \\
\text { Hari Kerja } \\
\text { Sesungguh } \\
\text { nya (hari) } \\
(3-4)=(5)\end{array}$ & $\begin{array}{c}(4: 3) \times 100 \\
\%=(6)\end{array}$ \\
\hline 1 & Januari & 32 & 27 & 864 & 34 & 830 & 3,9 \\
\hline 2 & Februari & 32 & 24 & 768 & 30 & 738 & 3,9 \\
\hline 3 & Maret & 32 & 26 & 832 & 36 & 796 & 4,3 \\
\hline \multirow[t]{3}{*}{4} & April & 32 & 26 & 832 & 35 & 797 & 4,2 \\
\hline & Total & 128 & 103 & 3,296 & 135 & 3,161 & 16,3 \\
\hline & Rata-rata & & 25,75 & 824 & 33,75 & 790,25 & 4,1 \\
\hline
\end{tabular}

Sumber: Data absensi dari Manager Artha Agung Resort and Restaurant, 2019

Sukrisno \& Ardana (2014) menyatakan rata-rata tingkat absensi 2-3 persen per bulan masih dianggap baik sedangkan tingkat absensi yang mencapai 15-20 persen per bulan menunjukkan gejala disiplin karyawan yang buruk. Tingkat absensi karyawan pada Artha Agung Resort and Restautant menunjukkan bahwa rata-rata tingkat absensi karyawan sebesar 4,1 persen, tingkat absensi ini melebihi tingkat toleransi perusahaan yaitu 3 persen. Hal ini menunjukkan gejala disiplin karyawan yang tidak baik. Kemangkiran atau tidak masuk kerja tanpa alasan (absen) merupakan keadaan yang tidak menguntungkan perusahaan.

Masalah sering tidak hadirnya karyawan ini dapat menjadi indikasi bahwa komitmen organisasional menurun. Berdasarkan penelusuran lebih jauh ke perusahaan diperoleh informasi bahwa sebagian besar karyawan pada perusahaan ini merasa terancam akan masa depan mereka yang disebabkan oleh kebanyakan perusahaan dalam pengadaan tenaga kerja, dengan model magang dan daily worker. Artha Agung Resort and Restautant ternyata jelas memiliki nilai-nilai yang menjadi budaya organisasi, dimana nilai-nilai ini selalu dijunjung tinggi oleh seluruh karyawan dan jajaran manajemen, yang tercermin dalam integritas, kerjasama, kegigihan, kemauan berprestasi. Namun dalam realitanya nilai-nilai yang telah menjadi budaya di Artha Agung Resort and Restaurant belum di laksanakan sepenuhnya dikalangan karyawan. Faktor lain yang diperoleh dalam hal lingkungan kerja, di perusahaan ini juga memiliki rasa kecemburuan sosial antar karyawan. Letak perusahaan di daerah dataran tinggi yang menyebabkan suhu udara yang dingin dan lembab, mengakibatkan karyawan yang tidak berasal dari daerah yang dingin menderita penyakit yang disebabkan oleh suhu dingin itu seperti asma ada 
karyawan merasa tidak nyaman untuk bekerja karena masalah kesehatan, yang menyebabkan sering absen bekerja.

Tujuan penelitian ini adalah: (1) menjelaskan pengaruh job insecurity terhadap komitmen organisasional (2) menjelaskan pengaruh budaya organisasi terhadap komitmen organisasional, dan (3) menjelaskan pengaruh lingkungan kerja terhadap komitmen organisasional.

Cropanzano \& Mitchell (2005) menjelaskan bahwa dasar teori pertukaran sosial (Social Exchange Theory) adalah hubungan yang meningkat dari waktu ke waktu menjadi hubungan yang saling mempercayai, loyal, dan saling berkomitmen selama kedua belah pihak menaati aturan-aturan pertukaran. Organisasi menawarkan kondisi kerja material dan immaterial kepada pegawai, sedangkan pegawai membalas upaya organisasi dengan bekerja keras. Ketika pegawai merasa diperlakukan adil dan merasa puas dengan organisasi, maka pegawai akan memberikan balasan yang positif bagi organisasi Giauque (2014). Teori pertukaran sosial menyoroti pentingnya memahami motivasi karyawan dan hubungannya dengan pencapaian tujuan organisasi. Pendekatan tersebut digunakan untuk memahami motif karyawan dalam melaksanakan kegiatan tertentu sebagai kewajiban timbal balik antara karyawan dan majikan Hamid et al. (2017).

Komitmen organisasional adalah sikap yang mencerminkan loyalitas karyawan terhadap organisasi mereka dan proses yang berkelanjutan di mana peserta organisasi mengekspresikan kepedulian mereka terhadap organisasi, kesuksesan, dan kesejahtraan (Luthans, 2005). Robbins (2013) menyatakan komitmen organisasi adalah suatu tingkatan anggota organisasi memihak kepada organisasi dan tujuan-tujuannya, dan berniat mempertahankan keanggotaannya dalam organisasi tersebut. Purnamasari \& Sriathi (2018) menyatakan komitmen organisasional ini juga dapat diartikan sebagai dorongan emosional diri dalam arti positif. Pegawai atau karyawan yang ingin karirnya maju, berkomitmen untuk mengejar keunggulan dan meraih prestasi, dan karyawan yang merasa penting terhadap pelayanan berkomitmen untuk meningkatkan kompetensi. Suhartini (2018) mengatakan komitmen organisasional merupakan dimensi perilaku penting yang dapat digunakan untuk menilai kecendrungan karyawan untuk bertahan sebagai anggota organisasi.

Job Insecurity adalah kondisi pisikologis seorang karyawan yang merasa bingung dan tidak aman, karena adanya kondisi lingkungan yang berubah-ubah, yang dapat mengancam keberlangsungan pekerjaannya (Septiari \& Ardana, 2015). Ridho (2017) mengemukakan bahwa job insecurity adalah kondisi karyawan dalam menjaga pekerjaan yang mengancam. Karyawan yang mempunyai dugaan tidak aman, cemas, resah, stress dan ketidakpastian berkaitan dengan perilaku dan keberadaan pekerjaannya dapat menyebabkan efek terhadap keinginan pindah karyawan. Ketidakamanan kerja yang muncul dari situasi diri sendiri serta lingkungan tempat bekerja akan menciptakan ketidaknyamanan dalam menjalankan pekerjaan serta kekhawatiran tentang kelangsungan pekerjaan (Anissa, 2017).

Budaya organisasi adalah seperangkat keyakinan yang dibagikan dan diterima secara personal serta dijadikan pegangan oleh suatu kelompok agar dapat menyesuaikan dengan lingkungan yang beragam. Pengertian ini berkaitan dengan 
karakteristi budaya organisasi yaitu budaya organisasi diberikan kepada pegawai baru melalui proses sosialisasi, budaya organisasi dapat mempengaruhi perilaku, dan budaya organisasi bekerja pada level yang berbeda (Kretner \& Kinichi, 2014).

Lingkungan kerja adalah keseluruhan alat perkakas dan bahan yang dihadapi, lingkungan sekitarnya di mana seseorang bekerja, metode kerjanya, serta pengaturan kerjanya baik sebagai perseorangan maupun sebagai kelompok Sedarmayanti (2009). Menurut Astrayana \& Sriathi (2014) lingkungan kerja dalam perusahaan dapat memengaruhi kinerja karyawan, jika lingkungan kerja perusahaan tersebut baik dan menunjang aktivitas karyawan, maka dapat meningkatkan kinerja karyawan. Lingkungan kerja perusahaan dikatakan baik apabila dapat memotivasi dan memberi kegairahan kerja atau semangat kerja karyawan untuk dapat melakukan pekerjaan yang lebih baik lagi dan memiliki dampak pada kinerja karyawan yang semakin baik juga.

Penelitian-penelitian tentang pengaruh job insecurity terhadap komitmen organisasional telah dilaksanakan oleh Iriana et al. (2004) pada akuntan pendidik menemukan bahwa job insecurity berpengaruh negatif terhadap komitmen organisasional. Hasil penelitian yang sama juga oleh Chirumbolo \& Areni (2005) menyatakan bahwa job insecurity memilki hubungan yang negatif terhadap shortterm organizational outcomes yang terdiri dari komitmen organisasional dan kepuasan kerja. Hasil penelitian ini juga sejalan oleh Yasmin (2011) menyatakan bahwa job insecurity berpengaruh negatif terhadap komitmen organisasional karyawan outsource PT. Asia Outsourcing Services yang ditempatkan di PT. X. Berdasarkan penelitian tersebut, rumusan hipotesis yang digunakan yaitu:

$\mathrm{H}_{1}$ : Job Insecurity berpengaruh negatif dan signifikan terhadap komitmen organisasional.

Penelitian-penelitian tentang pengaruh budaya organisasi terhadap komitmen organisasional telah dilaksanakan oleh Tanuwibowo \& Sutanto (2014) menyatakan budaya organisasi berpengaruh positif terhadap komitmen organisasional studi pada PT Tirta Sarana Sukses. Hasil penelitian ini juga sejalan oleh Khoiroh et al. (2018) yang menyatakan budaya organisasi berpengaruh positif terhadap komitmen organisasional dalam Meningkatkan Kinerja Pegawai pada Badan Perencanaan Pembangunan Daerah (BAPPEDA) Kabupaten Batang Hari. Wibawa \& Putra (2015) menyatakan bahwa budaya organisasi berpengaruh positif terhadap komitmen organisasional studi pada PT Bening Badung-Bali. Berdasarkan penelitian tersebut, rumusan hipotesis yang digunakan yaitu:

$\mathrm{H}_{2}$ : Budaya organisasi berpengaruh positif dan signifikan terhadap komitmen organisasional.

Penelitian-penelitian tentang pengaruh lingkungan kerja terhadap komitmen organisasional telah dilaksanakan oleh Subagyo (2014) yang dilakukan pada dosen perguruan tinggi menunjukkan bahwa lingkungan kerja berpengaruh positif terhadap komitmen organisasional. Hasil penelitian yang sama juga oleh Abidin et al. (2016) menyatakan bahwa lingkungan kerja berpengaruh positif dan signifikan terhadap komitmen organisasional di rumah sakit SMC Samarinda. Hasil penelitian ini juga sejalan oleh Saputra \& Andri (2017) mengenai pengaruh lingkungan kerja terhadap komitmen organisasional di mana ditemukan bahwa lingkungan kerja 
berpengaruh positif signifikan terhadap komitmen organisasional. Berdasarkan penelitian tersebut, rumusan hipotesis yang digunakan yaitu:

$\mathrm{H}_{3}$ : Lingkungan kerja berpengaruh positif dan signifikan terhadap komitmen organisasional.

\section{METODE PENELITIAN}

Desain penelitian ini menggunakan desain kuantitatif dan pendekatan berbentuk asosiatif yaitu suatu penelitian yang bertujuan mengetahui sebab dan akibat variabel-variaebl yang diteliti (Sugiyono, 2017). Variabel-variabel dalam penelitian ini terdiri dari variabel eksogen dan variabel endogen. Variabel-variabel yang diteliti diantaranya Job Insecurity $\left(\mathrm{X}_{1}\right)$, Budaya Organisasi $\left(\mathrm{X}_{2}\right)$ dan Lingkungan Kerja $\left(\mathrm{X}_{3}\right)$ sebagai variabel bebas serta Komitmen Organisasional (Y) sebagai variabel terikat. Semua data yang digunakan dalam penelitian ini, didukung oleh teori-teori empiris yang bertujuan untuk membuktikan hipotesis.

Penelitian ini dilakukan di Artha Agung Resort and Restaurant, Jl. Raya Besakih, Menanga, Karangasem. Alasan dilakukan penelitian di perusahaan tersebut, karena adanya permasalahan mengenai job insecurity, budaya organisasi, lingkungan kerja dan komitmen organisasional. Jenis data yang digunakan dalam penelitian ini adalah data kuantitatif yakni hasil kuesioner yang disebarkan oleh peneliti dan data kualitiatif adalah hasil pernyataan responden mengenai job insecurity, budaya organisasi, dan lingkungan kerja yang mempengaruhi komitmen organisasional. Sumber data dalam penelitian adalah data primer meliputi jawaban dari responden atas pernyataan kuesioner yang disebarkan oleh peneliti dan hasil wawancara dengan responden Artha Agung Resort and Restaurant.

Populasi dalam penelitian ini adalah seluruh karyawan Artha Agung Resort and Restaurant. Metode penentuan sampel yang digunakan adalah teknik sampel jenuh. Karena responden yang digunakan adalah seluruh karyawan Artha Agung Resort and Restaurant, sehingga sampel dari penelitian ini adalah 31. Manager tidak diikutsertakan sebagai sampel karena yang melakukan penilaian terhadap karyawan jika manager di ikut sertakan sebagai sampel akan memanipulasi data yang sebenarnya. Metode pengumpulan data yang digunakan dalam penelitian ini adalah kisioner. Kuesioner ini juga mempermudah dalam menulis data. Digunakan teknik manipulasi data yang sebelumnya ordinal menjadi data berbentuk interval dengan bantuan sekala Likert yang berguna untuk mengukur sikap, pendapat dan persepsi individu atau sekelompok orang mengenai fenomena sosial (Sugiyono, 2018).

\section{HASIL DAN PEMBAHASAN}

Sebelum dilakukan analisis data diperlukan pengujian instrumen untuk mendapatkan data yang valid dan reliabel. Uji validitas digunakan untuk mengukur sah atau tidaknya suatu kuesioner. Penyusunan ini dilakukan untuk menguji apakah instrumen penelitian yang digunakan dalam penelitian ini tepat. Suatu instrument dikatakan valid jika korelasi antara skor faktor dengan skor total bernilai positif dan 
nilainya lebih dari 0,30 ( $\mathrm{r}>0,3)$ dengan tingkat kesalahan Alpha 0,05. Tabel 2. berikut menyajikan hasil uji validitas instrumen penelitian.

Tabel 2.

Rekapitulasi Hasil Uji Validitas Instrumen Penelitian

\begin{tabular}{|c|c|c|c|c|}
\hline Variabel & Indikator & $\begin{array}{c}\text { Koefisien } \\
\text { Korelasi }\end{array}$ & $\begin{array}{l}\text { Sig. }(2- \\
\text { tailed })\end{array}$ & Keterangan \\
\hline \multirow{7}{*}{ Job insecurity $\left(\mathrm{X}_{1}\right)$} & $\mathrm{X}_{1.1}$ & 0,705 & 0,000 & Valid \\
\hline & $X_{1.2}$ & 0,699 & 0,000 & Valid \\
\hline & $\mathrm{X}_{1.3}$ & 0,664 & 0,000 & Valid \\
\hline & $\mathrm{X}_{1.4}$ & 0,603 & 0,000 & Valid \\
\hline & $\mathrm{X}_{1.5}$ & 0,671 & 0,000 & Valid \\
\hline & $\mathrm{X}_{1.6}$ & 0,700 & 0,000 & Valid \\
\hline & $\mathrm{X}_{2.1}$ & 0,765 & 0,000 & Valid \\
\hline \multirow{6}{*}{ Budaya organisasi $\left(\mathrm{X}_{2}\right)$} & $\mathrm{X}_{2.2}$ & 0,723 & 0,000 & Valid \\
\hline & $\mathrm{X}_{2.3}$ & 0,668 & 0,000 & Valid \\
\hline & $\mathrm{X}_{2.4}$ & 0,731 & 0,000 & Valid \\
\hline & $\mathrm{X}_{2.5}$ & 0,510 & 0,003 & Valid \\
\hline & $\mathrm{X}_{2.6}$ & 0,695 & 0,000 & Valid \\
\hline & $\mathrm{X}_{3.1}$ & 0,431 & 0,015 & Valid \\
\hline \multirow{10}{*}{ Lingkungan kerja $\left(\mathrm{X}_{3}\right)$} & $\mathrm{X}_{3.2}$ & 0,713 & 0,000 & Valid \\
\hline & $\mathrm{X}_{3.3}$ & 0,679 & 0,000 & Valid \\
\hline & $\mathrm{X}_{3.4}$ & 0,695 & 0,000 & Valid \\
\hline & $\mathrm{X}_{3.5}$ & 0,421 & 0,018 & Valid \\
\hline & $\mathrm{X}_{3.6}$ & 0,570 & 0,001 & Valid \\
\hline & $\mathrm{X}_{3.7}$ & 0,794 & 0,000 & Valid \\
\hline & $\mathrm{X}_{3.8}$ & 0,629 & 0,000 & Valid \\
\hline & $\mathrm{X}_{3.9}$ & 0,659 & 0,000 & Valid \\
\hline & $\mathrm{X}_{3.10}$ & 0,475 & 0,007 & Valid \\
\hline & $\mathrm{X}_{3.11}$ & 0,551 & 0,001 & Valid \\
\hline \multirow{10}{*}{$\begin{array}{c}\text { Komitmen } \\
\text { organisasional }(\mathrm{Y})\end{array}$} & $\mathrm{X}_{3.12}$ & 0,365 & 0,044 & Valid \\
\hline & $\mathrm{Y}_{1}$ & 0,598 & 0,000 & Valid \\
\hline & $\mathrm{Y}_{2}$ & 0,740 & 0,000 & Valid \\
\hline & $\mathrm{Y}_{3}$ & 0,728 & 0,000 & Valid \\
\hline & $\mathrm{Y}_{4}$ & 0,520 & 0,003 & Valid \\
\hline & $\mathrm{Y}_{5}$ & 0,610 & 0,000 & Valid \\
\hline & Y6 & 0,595 & 0,000 & Valid \\
\hline & Y7 & 0,541 & 0,002 & Valid \\
\hline & Y8 & 0,571 & 0,001 & Valid \\
\hline & Y9 & 0,430 & 0,016 & Valid \\
\hline
\end{tabular}

Sumber: Data Penelitian, 2019 
Tabel 3.

Rekapitulasi Hasil Uji Reliabilitas Instrumen Penelitian

\begin{tabular}{clcc}
\hline No. & \multicolumn{1}{c}{ Variabel } & Cronbach's Alpha & Keterangan \\
\hline 1 & Job insecurity $\left(\mathrm{X}_{1}\right)$ & 0,753 & Reliabel \\
2 & Budaya organisasi $\left(\mathrm{X}_{2}\right)$ & 0,770 & Reliabel \\
3 & Lingkungan kerja $\left(\mathrm{X}_{3}\right)$ & 0,827 & Reliabel \\
4 & Komitmen organisasional $(\mathrm{Y})$ & 0,772 & Reliabel \\
\hline
\end{tabular}

Sumber: Data Penelitian, 2019

Tabel 4.

Karakteristik Karyawan Artha Agung Resort and Restaurant

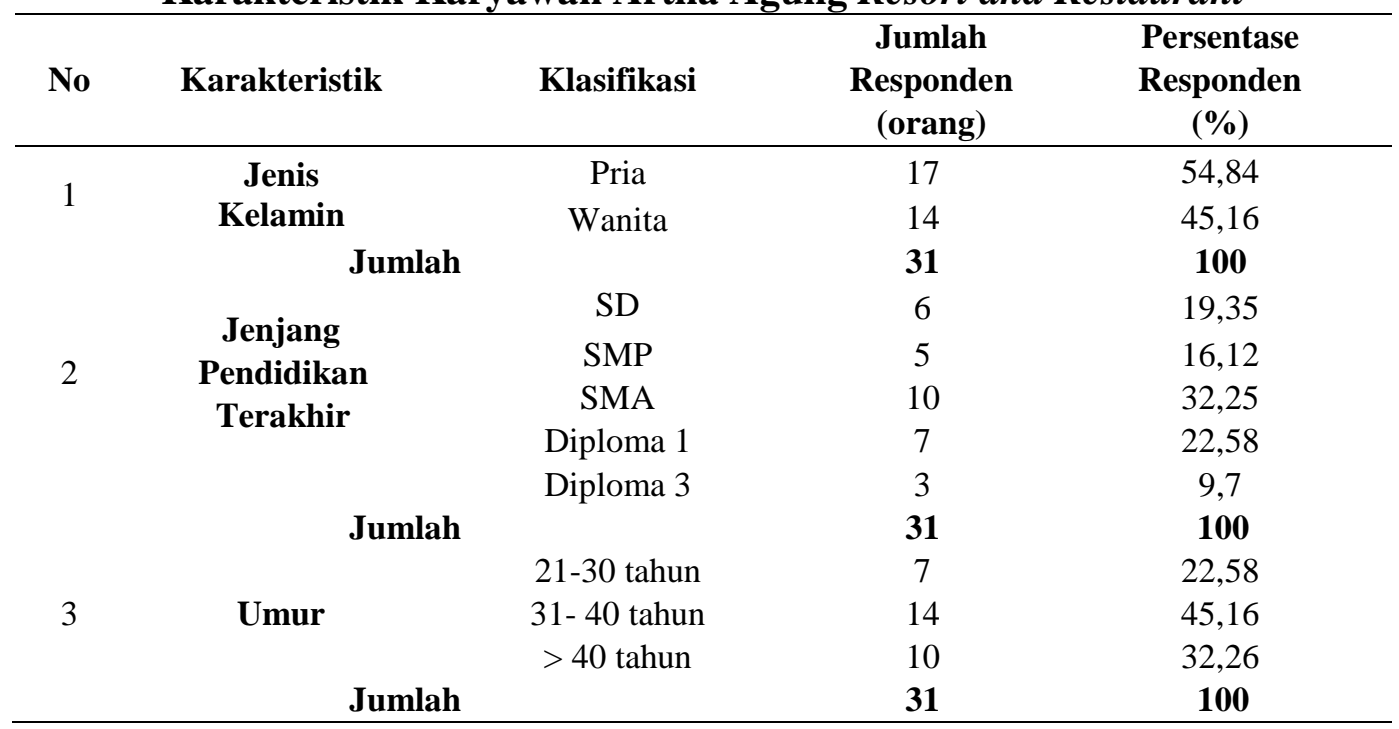

Sumber: Data Penelitian, 2019

Tabel 2. dan 3. menginformasikan bahwa model telah memiliki validitas dan reliabilitas yang memadai. Hal tersebut terlihat dari seluruh instrumen penelitian yang digunakan memiliki nilai koefisien korelasi dengan skor total seluruh item pernyataan lebih besar dari 0,30 dengan signifikansi kurang dari 0,05. Dan untuk uji reliabilitas menunjukkan seluruh instrumen penelitian memiliki koefisien Cronbach's Alpha lebih dari 0,60.

Pada Tabel 4. menunjukkan bahwa responden didominasi oleh pria sebanyak 54,84 persen, sedangkan wanita sebanyak 45,16 persen. Pendidikan terakhir yang didominasi oleh karyawan yang memiliki tingkat SMA yaitu sebesar 32,25 persen, kemudian diikuti oleh karyawan yang memiliki tingkat pendidikan Diploma 1 yaitu sebesar 22,58 persen, karyawan yang memiliki tingkat pendidikan SD yaitu sebesar 19,35 persen, karyawan yang memiliki tingkat pendidikan SMP yaitu sebesar 16,12 persen, karyawan yang memiliki tingkat pendidikan Diploma 3 yaitu sebesar 9,7 persen. Berdasarkan klasifikasi umur, hasil penelitian ini menunjukkan bahwa responden berusia 21 - 30 tahun yaitu sebesar 22,58 persen, responden berusia 31- 
40 tahun yaitu sebesar 45,16 persen, responden berusia $>40$ tahun yaitu sebesar 32,26 persen.

Tabel 5.

Deskripsi Jawaban Responden Mengenai Variabel Job Insecurity

\begin{tabular}{|c|c|c|c|c|c|c|c|c|c|}
\hline \multirow[t]{2}{*}{ No } & \multirow[t]{2}{*}{ Indikator } & \multicolumn{5}{|c|}{ Skor Jawaban } & \multirow{2}{*}{$\begin{array}{c}\text { Jumlah } \\
\text { Skor }\end{array}$} & \multirow{2}{*}{$\begin{array}{l}\text { Rata- } \\
\text { Rata- }\end{array}$} & \multirow[t]{2}{*}{ Ket. } \\
\hline & & 1 & 2 & 3 & 4 & 5 & & & \\
\hline 1 & $\begin{array}{l}\text { Saya merasa pekerjaan } \\
\text { yang saya lakukan } \\
\text { sangat penting bagi } \\
\text { organisasi. }\end{array}$ & 0 & 2 & 15 & 11 & 3 & 108 & 3,48 & Tinggi \\
\hline 2 & $\begin{array}{l}\text { Saya sangat takut jika } \\
\text { pekerjaan yang saya } \\
\text { lakukan terdapat } \\
\text { banyak kesalahan } \\
\text { yang saya perbuat. }\end{array}$ & 0 & 3 & 16 & 8 & 4 & 106 & 3,41 & Tinggi \\
\hline 3 & $\begin{array}{l}\text { Kesalahan yang saya } \\
\text { lakukan } \\
\text { mempengaruhi masa } \\
\text { depan pekerjaan atau } \\
\text { karir saya. }\end{array}$ & 0 & 1 & 7 & 18 & 5 & 120 & 3,87 & Tinggi \\
\hline 4 & $\begin{array}{l}\text { Tingkat kesalahan } \\
\text { yang saya lakukan } \\
\text { memungkinkan saya } \\
\text { dikeluarkan dari } \\
\text { pekerjaan. }\end{array}$ & 0 & 2 & 8 & 14 & 7 & 119 & 3,83 & Tinggi \\
\hline 5 & $\begin{array}{l}\text { Saya tidak selalu } \\
\text { mengantisipasi tiap } \\
\text { kesalahan yang saya } \\
\text { lakukan, sehingga } \\
\text { kesalahan yang saya } \\
\text { perbuat tidak } \\
\text { mengancam pekerjaan } \\
\text { saya. }\end{array}$ & 0 & 1 & 9 & 20 & 1 & 114 & 3,67 & Tinggi \\
\hline 6 & $\begin{array}{l}\text { Saya melanggar aturan } \\
\text { di tempat saya bekerja } \\
\text { untuk menutupi } \\
\text { kesalahan yang saya } \\
\text { lakukan. }\end{array}$ & 0 & 3 & 11 & 14 & 3 & 110 & 3,54 & Tinggi \\
\hline
\end{tabular}

Sumber: Data Penelitian, 2019

Hasil deskripsi jawaban responden pada Tabel 5. menunjukkan bahwa 6 pernyataan mengenai variabel job insecurity dengan rata-rata skor sebesar 3,63 dan 
masuk dalam kategori tinggi, ini berarti responden memiliki persepsi yang tinggi mengenai job insecurity pada karyawan Artha Agung Resort and Restaurant berada pada posisi tinggi. Skor tertinggi sebesar 3,87 adalah pernyataan ketiga yaitu "Kesalahan yang saya lakukan mempengaruhi masa depan pekerjaan karir saya" dan masuk dalam kriteria tinggi, hal ini berarti bahwa responden berpandangan bahwa ketidakamaan kerja pada karyawan Artha Agung Resort and Restaurant tinggi sehingga karyawan dalam menjalankan tugas fungsinya berusaha secara maksimal agar tidak terjadi kesalahan yang dapat mengancam pekerjaannya. Skor terendah sebesar 3,41 merujuk pada pernyataan kedua yaitu "Saya sangat takut jika pekerjaan yang saya lakukan terdapat banyak kesalahan yang saya perbuat" masuk kategori tinggi yang berarti responden berpandangan bahwa karyawan menjalankan tugasnya sesuai dengan apa aturan yang berlaku.

Tabel 6.

Deskripsi Jawaban Responden Mengenai Variabel Budaya Organisasi

No Indikator Skor Jawaban Jumlah Rata- Ket.

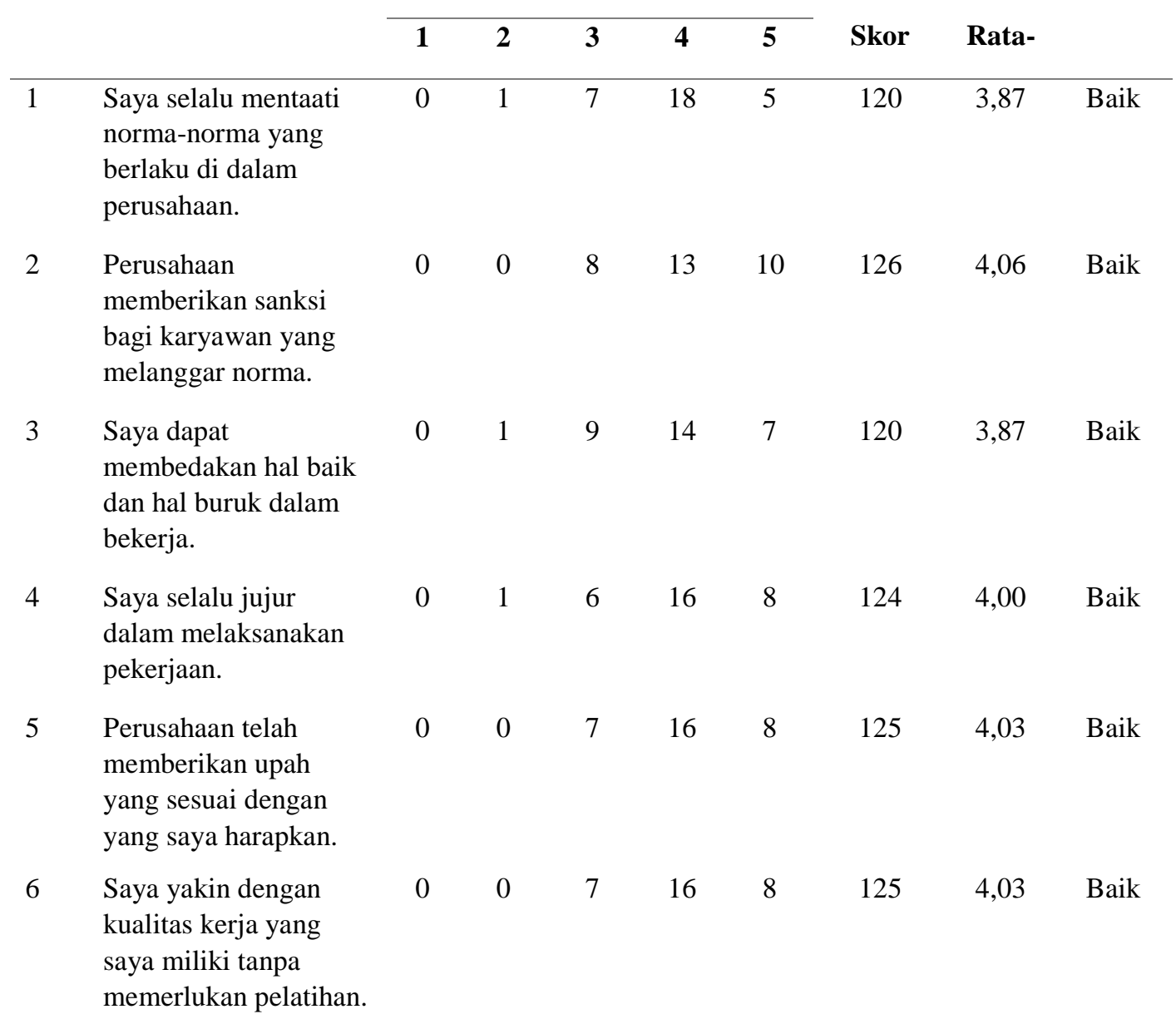

Budaya Organisasi $\quad 3,97 \quad$ Baik 
Hasil deskripsi jawaban responden pada Tabel 6. menunjukkan bahwa 6 pernyataan mengenai variabel budaya organisasi dengan rata-rata skor sebesar 3,63 dan masuk dalam kategori tinggi, ini berarti responden memiliki persepsi yang tinggi mengenai budaya organisasi pada karyawan Artha Agung Resort and Restaurant berada pada posisi baik. Skor tertinggi sebesar 4,06 adalah pernyataan kedua yaitu "Perusahaan memberikan sanksi bagi karyawan yang melanggar norma" dan masuk dalam kriteria baik hal ini berarti bahwa responden berpandangan bahwa budaya organisasi pada Artha Agung Resort and Restaurant baik sehingga karyawan dalam menjalankan tugas fungsinya sesuai dengan norma dan aturan yang berlaku. Skor terendah sebesar 3,87 merujuk pada pernyataan pertama dan ketiga yaitu "Saya selalu menaati norma-norma yang berlaku di dalam perusahaan" dan "Saya selalu jujur dalam melaksanakan pekerjaan" masuk kategori baik berarti responden berpandangan bahwa karyawan menjalankan tugasnya secara jujur sesuai dengan norma yang berlaku. Hal ini berarti, responden menganggap budaya organisasi pada karyawan Artha Agung Resort and Restaurant baik.

\section{Tabel 7.}

Deskripsi Jawaban Responden Mengenai Variabel Komitmen Organisasional

\begin{tabular}{|c|c|c|c|c|c|c|c|c|c|}
\hline \multirow[t]{2}{*}{ No } & \multirow[t]{2}{*}{ Indikator } & \multicolumn{5}{|c|}{ Skor Jawaban } & \multirow{2}{*}{$\begin{array}{c}\text { Jumlah } \\
\text { Skor }\end{array}$} & \multirow{2}{*}{$\begin{array}{l}\text { Rata- } \\
\text { Rata- }\end{array}$} & \multirow[t]{2}{*}{ Ket. } \\
\hline & & 1 & 2 & 3 & 4 & 5 & & & \\
\hline 1 & $\begin{array}{l}\text { Saya senang } \\
\text { menghabiskan waktu } \\
\text { kerja dalam organisasi. }\end{array}$ & 0 & 1 & 8 & 14 & 8 & 122 & 3,93 & Tinggi \\
\hline 2 & $\begin{array}{l}\text { Saya bersedia } \\
\text { melakukan apapun } \\
\text { demi kemajuan } \\
\text { organisasi. }\end{array}$ & 0 & 2 & 6 & 12 & 11 & 123 & 3,96 & Tinggi \\
\hline 3 & $\begin{array}{l}\text { Saya bekerja dalam } \\
\text { organisasi merupakan } \\
\text { suatu kewajiban. }\end{array}$ & 0 & 2 & 10 & 10 & 9 & 119 & 3,83 & Tinggi \\
\hline 4 & $\begin{array}{l}\text { Saya tidak akan } \\
\text { merasa tenang jika } \\
\text { meninggalkan } \\
\text { organisasi. }\end{array}$ & 0 & 2 & 8 & 15 & 6 & 118 & 3,80 & Tinggi \\
\hline 5 & $\begin{array}{l}\text { Saya sulit } \\
\text { mendapatkan } \\
\text { pekerjaan seperti } \\
\text { sekarang dengan } \\
\text { penghasilan yang } \\
\text { bagus. }\end{array}$ & 0 & 0 & 7 & 20 & 4 & 121 & 3,90 & Tinggi \\
\hline 6 & $\begin{array}{l}\text { Saya sangat dirugikan } \\
\text { jika keluar dari } \\
\text { organisasi. }\end{array}$ & 0 & 1 & 4 & 15 & 11 & 129 & 4,16 & Tinggi \\
\hline
\end{tabular}


Lanjutan Tabel 7.

\begin{tabular}{|c|c|c|c|c|c|c|c|c|c|}
\hline \multirow[t]{2}{*}{ No } & \multirow[t]{2}{*}{ Indikator } & \multicolumn{5}{|c|}{ Skor Jawaban } & \multirow{2}{*}{$\begin{array}{c}\text { Jumlah } \\
\text { Skor }\end{array}$} & \multirow{2}{*}{$\begin{array}{l}\text { Rata- } \\
\text { Rata- }\end{array}$} & \multirow[t]{2}{*}{ Ket. } \\
\hline & & 1 & 2 & 3 & 4 & 5 & & & \\
\hline 7 & $\begin{array}{l}\text { Saya bersedia untuk } \\
\text { terlibat dalam setiap } \\
\text { kegiatan organisasi. }\end{array}$ & 1 & 2 & 5 & 18 & 6 & 122 & 3,93 & Tinggi \\
\hline 8 & $\begin{array}{l}\text { Organisasi ini sangat } \\
\text { layak mendapatkan } \\
\text { kesetiaan dari saya. }\end{array}$ & 0 & 1 & 11 & 13 & 6 & 177 & 3,77 & Tinggi \\
\hline \multirow[t]{2}{*}{9} & $\begin{array}{l}\text { Saya bangga menjadi } \\
\text { bagian dari organisasi. }\end{array}$ & 0 & 0 & 8 & 17 & 6 & 139 & 4,48 & $\begin{array}{l}\text { Sangat } \\
\text { Tinggi }\end{array}$ \\
\hline & \multicolumn{7}{|c|}{ Komitmen Organisasional } & 3,97 & Baik \\
\hline
\end{tabular}

Sumber: Data Penelitian, 2019

Hasil deskripsi jawaban responden pada Tabel 7. menunjukkan bahwa 9 pernyataan mengenai variabel komitmen organisasional, dengan rata-rata skor sebesar 3,97 dan masuk dalam kategori tinggi, ini berarti responden memiliki persepsi yang tinggi mengenai komitmen organisasional pada karyawan Artha Agung Resort and Restaurant berada pada posisi tinggi.

Skor tertinggi sebesar 4,48 adalah pernyataan kesembilan yaitu "Saya bangga menjadi bagian dari organisasi." dan masuk dalam kriteria sangat tinggi, hal ini berarti bahwa responden berpandangan bahwa komitmen organisasional pada karyawan Artha Agung Resort and Restaurant sangat tinggi, hal ini dibuktikan dengan karyawan merasa sangat bangga menjadi bagian dari organisasi. Skor terendah sebesar 3,77 merujuk pada pernyataan kedelapan yaitu "Organisasi ini sangat layak mendapatkan kesetiaan dari saya" masuk kategori tinggi yang berarti responden berpandangan Artha Agung Resort and Restaurant layak mendapatkan kesetian dari para karyawannya.

Uji normalitas bertujuan untuk mengetahui apakah residual dari model regresi yang dibuat berdistribusi normal atau tidak dengan menggunakan uji KolmogorovSminorv. Apabila koefisien Asymp.Sig.(2-tailed) lebih besar dari 0,05 maka data tersebut dikatakan berdistribusi normal. Berdasarkan hasil analisis uji Normalitas didapat nilai uji Kolmogorov-Smirnov sebesar 0,732 dengan nilai signifikansi pada Asymp. Sig. (2-tailed) sebesar 0,657. Nilai signifikansi 0,657 lebih dari 0,05 maka dapat disimpulkan bahwa model persamaan regresi berdistribusi normal.

Uji multikolinearitas bertujuan untuk menguji apakah di dalam model regresi ditemukan adanya korelasi antar variabel-variabel bebas. Berdasarkan hasil penelitian ini menunjukkan bahwa bahwa nilai tolerance dan VIF dari seluruh variable tersebut menunjukkan bahwa nilai tolerance untuk setiap variabel lebih besar dari 10 persen atau 0,1 dan nilai VIF lebih kecil dari 10 yang berarti model persamaan regresi bebas dari multikolinearitas. 
Uji heteroskedastisitas bertujuan untuk menguji model regresi apakah terjadi ketidaksamaan varian dari residual satu pengamatan ke pengamatan lain. Uji ini dapat dianalisis melalui uji glejser dengan melihat tingkat signifikansi. Hasill uji heteroskedastisitas menunjukkan bahwa bahwa nilai

Signifikansi dari variabel job insecurity adalah sebesar 0,585, kemudian budaya organisasi sebesar 0,850 dan nilai signifikansi Lingkungan kerja adalah sebesar 0,154. Nilai masing-masing variabel memiliki nilai yang lebih besar dari 0,05 yang berarti tidak terdapat pengaruh antara variabel bebas terhadap absolute residual. Dengan demikian, model yang dibuat tidak mengandung gejala heteroskedastisitas.

Setelah semua asumsi klasik terpenuhi, maka selanjutnya memaparkan hasil analisis regresi linier berganda. Perhitungan koefisien regresi linier berganda dilakukan dengan analisis regresi melalui software SPSS 18.0 for Windows, diperoleh hasil yang ditunjukan pada Tabel 8 .

Tabel 8.

Hasil Analisis Regresi Linier Berganda

\begin{tabular}{|c|c|c|c|c|c|c|}
\hline \multirow{2}{*}{\multicolumn{2}{|c|}{ Model }} & \multicolumn{2}{|c|}{$\begin{array}{c}\text { Unstandardized } \\
\text { Coefficients } \\
\end{array}$} & \multirow{2}{*}{$\begin{array}{c}\begin{array}{c}\text { Standardized } \\
\text { Coefficients }\end{array} \\
\text { Beta } \\
\end{array}$} & \multirow[b]{2}{*}{$\mathbf{t}$} & \multirow[b]{2}{*}{ Sig. } \\
\hline & & B & Std. Error & & & \\
\hline \multirow[t]{8}{*}{1} & (Constant) & 13,007 & 5,529 & & 2,352 & 0,026 \\
\hline & Job insecurity & $-0,321$ & 0,132 & $-0,233$ & $-2,436$ & 0,022 \\
\hline & Budaya organisasi & 0,468 & 0,154 & 0,335 & 3,032 & 0,005 \\
\hline & Lingkungan kerja & 0,371 & 0,066 & 0,541 & 5,587 & 0,000 \\
\hline & R Square & 0,828 & & & & \\
\hline & Adjusted R Square & 0,809 & & & & \\
\hline & F Statistik & 43,451 & & & & \\
\hline & Signifikansi Uji F & 0,000 & & & & \\
\hline
\end{tabular}

Sumber: Data Penelitian, 2019

Berdasarkan hasil analisis regresi linier berganda seperti yang disajikan pada Tabel 8, maka dapat dibuat persamaan regresi sebagai berikut.

$$
\mathrm{Y}=13,007-0,321 \mathrm{X}_{1}+0,468 \mathrm{X}_{2}+0,371 \mathrm{X}_{3}
$$

Nilai koefisien regresi masing-masing variabel budaya organisasi dan lingkungan kerja bernilai positif dengan nilai signifikansi uji t kurang dari 0,05. Hal ini menunjukkan bahwa budaya organisasi dan lingkungan kerja memiliki pengaruh positif yang signifikan terhadap variabel terikat. Sedangkan job insecurity bernilai negatif dengan nilai signifikansi uji t kurang dari 0,05 , yang berarti job insecurity berpengaruh negatif signifikan pada variabel terikat. Berikut penjelasan mengenai hasil analisis regresi berganda, terdiri atas uji kelayakan model (uji F), koefisien determinasi $\left(\mathrm{R}^{2}\right)$, dan uji hipotesis (uji $\mathrm{t}$ ).

Uji kelayakan model regresi bertujuan untuk mengetahui apakah semua variabel bebas yang diidentifikasi (job insecurity, budaya organisasi, Lingkungan kerja) tepat digunakan memprediksi komitmen organisasional. Uji ini sering juga disebut dengan uji $\mathrm{F}$. Hasil uji $\mathrm{F}$ yang di analisis dengan menggunakan program

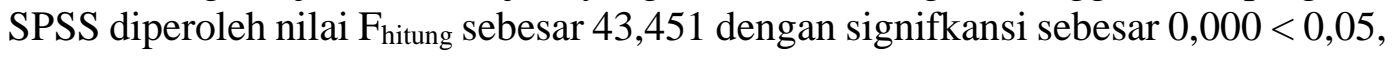
maka dapat disimpulkan bahwa pada kelompok yang diuji memiliki perbedaan 
yang nyata (signifikan). Hasil ini mempunyai arti bahwa ada pengaruh signifikan antara job insecurity, budaya organisasi, dan Lingkungan kerja secara simultan terhadap komitmen organisasional pada Artha Agung Resort and Restaurant.

Koefisien determinasi $\left(\mathrm{R}^{2}\right)$ digunakan untuk mengetahui dan mengukur kemampuan model dalam menerangkan variasi variabel independen. Besarnya pengaruh variabel bebas terhadap variabel terikat yang ditunjukkan oleh nilai determinasi total (R Square) pada Tabel 4.9 menunjukkan nilai sebesar 0,828. Nilai $\mathrm{R}$ Square sebesar 0,828 mempunyai arti bahwa sebesar 82,8 persen variasi komitmen organisasional pada Artha Agung Resort and Restaurant dipengaruhi oleh variasi job insecurity, budaya organisasi, dan Lingkungan kerja, sedangkan sisanya sebesar 17,2 persen djelaskan oleh faktor lain yang tidak dimasukkan ke dalam model.

Berdasarkan hasil analisis pengaruh job insecurity terhadap komitmen organisasional diperoleh nilai signifikasi sebesar 0,022 dengan nilai koefisien regresi yang bernilai negatif sebesar -0,321. Nilai Signifikansi 0,022 < 0,050 mengindikasikan bahwa $\mathrm{H}_{1}$ diterima. Hasil ini mempunyai arti bahwa job insecurity berpengaruh negatif dan signifikan terhadap komitmen organisasional pada Artha Agung Resort and Restaurant.

Berdasarkan hasil analisis pengaruh budaya organisasi terhadap komitmen organisasional diperoleh nilai signifikansi sebesar 0,005 dengan nilai koefisien regresi yang bernilai positif sebesar 0,468. Nilai Signifikansi 0,005<0,050 mengindikasikan bahwa $\mathrm{H}_{2}$ diterima. Hasil ini mempunyai arti bahwa budaya organisasi berpengaruh positif dan signifikan terhadap komitmen organisasional pada Artha Agung Resort and Restaurant.

Berdasarkan hasil analisis pengaruh Lingkungan kerja terhadap komitmen organisasional diperoleh nilai signifikansi sebesar 0,000 dengan nilai koefisien regresi yang bernilai positif sebesar 0,371. Nilai signifikansi $0,000<0,050$ mengindikasikan bahwa $\mathrm{H}_{0}$ ditolak dan $\mathrm{H}_{3}$ diterima. Hasil ini mempunyai arti bahwa Lingkungan kerja berpengaruh positif dan signifikan komitmen organisasional pada Artha Agung Resort and Restaurant.

$J o b$ insecurity adalah kondisi karyawan dalam menjaga pekerjaan yang mengancam. Karyawan yang mempunyai dugaan tidak aman, cemas, resah, stress dan ketidakpastian berkaitan dengan perilaku dan keberadaan pekerjaannya dapat menyebabkan efek terhadap keinginan pindah karyawan (Ridho, 2017) Hasil analisis menunjukkan bahwa job insecurity berpengaruh negatif dan signifikan terhadap komitmen organisasional, yakni berarti semakin tinggi job insecurity yang dirasakan karyawan Artha Agung Resort and Restaurant maka komitmen organisasional karyawan akan semakin berkurang. Begitu pula sebaliknya, semakin rendah job insecurity yang dirasakan karyawan Artha Agung Resort and Restaurant, maka akan semakin meningkatkan komitmen organisasional.

Hasil penelitian ini sesuai dengan dasar teori pertukaran sosial (Social Exchange Theory). Teori ini menyatakan bahwa ketidakamanan kerja akan mengurangi rasa komitmen organisasi karyawan, sedangkan kenyamanan dalam bekerja akan membuat karyawan merasa puas dan diperlakukan adil dengan organisasi, sehingga pegawai akan memberikan balasan yang positif bagi organisasi dan pada akhirnya komitmen organisasi karyawan akan semakin meningkat. 
Hasil ini mendukung penelitian yang dilakukan oleh Iriana et al. (2004) yang menyatakan bahwa job insecurity berpengaruh negatif terhadap komitmen organisasional. Semakin karyawan merasa tidak aman bekerja dalam suatu organisasi maka dapat mengurangi tingkat komitmen organisasional karyawan. Hasil penelitian ini juga sesuai dengan temuan Chirumbolo \& Areni (2005); Yasmin, (2011); Ezra et al. (2019) yang menyatakan bahwa job insecurity memilki hubungan yang negatif terhadap komitmen organisasional karyawan.

Hasil analisis menunjukkan bahwa budaya organisasi berpengaruh positif dan signifikan terhadap komitmen organisasional, yang berarti bahwa semakin baik penerapan budaya organisasi pada Artha Agung Resort and Restaurant maka komitmen organisasional yang dimiliki karyawan akan semakin bertambah. Begitu pula sebaliknya, semakin buruk penerapan budaya organisasi seorang pegawai, maka semakin rendah tingkat komitmen organisasional yang akan terbentuk.

Hasil penelitian ini sesuai dengan dasar teori pertukaran sosial (Social Exchange Theory). Teori ini menyatakan bahwa budaya organisasi yang baik akan membentuk hubungan yang meningkat dari waktu ke waktu menjadi hubungan yang saling mempercayai, loyal, dan saling berkomitmen diantara karyawan dan organisasi. Ketika pegawai merasa diperlakukan adil dan merasa puas dengan organisasi, maka pegawai akan memberikan balasan yang positif bagi organisasi (Giauque, 2014).

Hasil ini didukung temuan Rahmi \& Mulyadi (2018) yang menyatakan bahwa budaya organisasi memiliki pengaruh positif terhadap komitmen organisasional. Penelitian ini konsisten dengan hasil penelitian yang dilakukan oleh Khoiroh et al. (2018) yang menyatakan Budaya Organisasi berpengaruh positif terhadap Komitmen Organisasional. Hasil penelitian ini juga mendukung hasil penelitian Reskantika et al. (2019), Faisal \& Dewi. (2019) yang menyatakan budaya organisasi berpengaruh positif terhadap komitmen organisasional karyawan, hal ini berarti perusahaan diharapkan agar mempertahankan budaya berupa norma-norma dan nilai-nilai yang diterapkan di perusahaan tetap terjaga sehingga dapat meningkatkan komitmen organisasional karyawan untuk tetap tinggal di perusahaan.

Lingkungan kerja merupakan salah satu aspek penting yang dapat digunakan untuk mendorong komitmen organisasional karyawan. Lingkungan kerja yang baik dimunculkan untuk memotivasi dan mempengaruhi seorang karyawan agar tetap semangat dalam menjalankan tugas-tugas yang diberikan, misalnya seperti keadaan penerangan atau cahaya di tempat, keadaan udara ditempat kerja, keadaan suara di tempat kerja serta keadaan perlengkapan kerja (Putra \& Sriathi, 2019).

Hasil analisis menunjukkan bahwa Lingkungan kerja berpengaruh positif dan signifikan terhadap komitmen organisasional, yang berarti bahwa semakin baik kondisi lingkungan kerja yang dirasakan oleh karyawan Artha Agung Resort and Restaurant maka akan berpengaruh pada semakin meningkatnya komitmen organisasional tersebut. Begitu pula sebaliknya, semakin buruk kondisi lingkungan kerja yang diterima pegawai, maka akan berpengaruh pada semakin berkurangnya komitmen organisasional pada Artha Agung Resort and Restaurant.

Hasil penelitian ini sesuai dengan dasar teori pertukaran sosial (Social Exchange Theory). Teori ini menyatakan bahwa lingkungan kerja yang baik akan 
membentuk hubungan yang meningkat dari waktu ke waktu menjadi hubungan yang saling mempercayai, loyal, dan saling berkomitmen diantara karyawan dan organisasi. Teori ini juga menyatakan bahwa lingkungan kerja dapat digunakan sebagai motivasi karyawan agar lebih semangat untuk bekerja. Hal ini sesuai dengan teori pertukaran sosial yang menyoroti pentingnya memahami motivasi karyawan dan hubungannya dengan pencapaian tujuan organisasi. Pendekatan tersebut digunakan untuk memahami motif karyawan dalam melaksanakan kegiatan tertentu sebagai kewajiban timbal balik antara karyawan dan perusahaan (Hamid et al, 2017).

Hasil ini mendukung penelitian Saputra \& Andri (2017) yang menyatakan bahwa lingkungan kerja berpengaruh positif signifikan terhadap komitmen organisasional. Hasil penelitian tersebut sejalan dengan penelitian yang dilakukan Herjany \& Bernartoyang, (2018) yang menunjukkan bahwa lingkungan kerja berpengaruh positif terhadap komitmen organisasional. Selanjutnya pada penelitian Faisal \& Dewi, (2019) juga menyatakan bahwa Lingkungan kerja berpengaruh positif terhadap komitmen organisasional karyawan yang artinya semakin baik lingkungan kerja spada perusahaan, maka semakin tinggi komitmen karyawan untuk tetap berorganisasi di perusahaan.

\section{SIMPULAN}

Job insecurity berpengaruh negatif dan signifikan terhadap komitmen organisasional, sehingga hipotesis satu diterima. Hal ini berarti bahwa semakin tinggi job insecurity yang dirasakan karyawan maka komitmen organisasional karyawan akan semakin rendah. Budaya organisasi berpengaruh positif dan signifikan terhadap komitmen organisasional, sehingga hipotesis kedua diterima. Hal ini berarti bahwa semakin baik penerapan budaya organisasi maka komitmen organisasional karyawan akan semakin tinggi. Lingkungan kerja berpengaruh positif dan signifikan terhadap komitmen organisasional, sehingga hipotesis ketiga diterima. Hal ini berarti bahwa semakin baik kondisi lingkungan kerja semakin tinggi komitmen organisasional.

Pihak perusahaan sebaiknya dapat mengevaluasi dan meminimalisir job insecurity, agar komitmen organisaional karyawan meningkat. Pihak perusahaan sebaiknya meningkatkan norma-norma dan aturan agar karyawan semakin taat dan disiplin yang dapat menciptakan budaya organisasi yang baik bagi perusahaan. Pihak perusahaan sebaiknya meningkatkan penerangan agar dapat mempermudah pekerjaan, dan memperhatikan lingkungan kerja yang lainnya agar tercipta lingkungan kerja yang baik bagi karyawan. Bagi peneliti selanjutnya yang ingin melakukan penelitian terkait, diharapkan melakukan penelitian pada variabelvariabel baru dan lebih bervariasi serta memperkaya referensi tentang komitmen organisasional.

\section{REFERENSI}


Abidin, M. I. Z., Pangtularan, Y., \& Maria, S. (2016). Pengaruh Kepuasan Kerja, Lingkungan Kerja, Efikasi Diri terhadap Komitmen Organisasi di Rumah Sakit SMC Samarinda. Jurnal Ekonomi dan Keuangan. 13(1), 1-10.

Adkins, C. L. J. D. W., \& Jing. L. (2001). A Field Study of Job Insecurity During A Financial Crisis. Journal of Group and Organizational Management. 26(4): 463-483.

Angelia, N. (2013) Hubungan Antara Kualitas Kehidupan Kerja dengan Komitmen Organisasi Pada Karyawan Perusahaan Genteng Muria. Empaty Jurnal Fakultas Psikologi. Yogyakarta. 2(1): 1-15.

Anissa, A. (2017). Pengaruh Ketidakamanan Kerja, Kepuasan Kerja Dan Komitmen Organisasi Terhadap Turnover Intention Pada PT. Riau Crumb Rubber Factory (RICRY) Pekanbaru. 4(1). 364-375.

Astrayana. T. K., \& Sriathi. A. A. (2014). Pengaruh Pendidikan Dan Pelatihan, Insentif Finansial, Dan Lingkungan Kerja Fisik Terhadap. E-jurnal Manajemen Universitas Udayana, 3097-3116.

Chirumbolo, A., \& Areni, A. (2005). The Influence of Job Insecurity on Job Performance And Absenteeism: The Moderating Effect of Work Attitudes. Journal of Industrial Psychology, 65-71.

Cropanzano, R., \& M. S. Mitchell. (2005). Social Exchange Theory: An Interdisciplinary Review. Journal of Management, 31, 874-900.

Dewi, I.G. A.K.R., \& Surya, I. B. K. (2017). Pengaruh Budaya Organisasi Terhadap Komitmen Organisasional dan Organizational Silence Pada PT. PLN (PERSERO) Rayon Denpasar. E-Jurnal Manajemen Unud. 6(1), 289-316.

Ezra, R.,, R. Fitria. Y. \& Syahrizal. (2019). Pengaruh Ketidakamanan Kerja terhadap Intensi Keluar dengan Komitmen Organisasional Sebagai Variabel Mediasi Pada Perawat Kontrakrumah Sakit Umum Citra BMC Padang. Jurnal Kajian Manajemen dan Wirausaha. 1(1), 183-191.

Faisal. N., \& Dewi., M. (2019). Pengaruh Kompensasi, Lingkungan Kerja, Dan Budaya Organisasi Terhadap Komitmen Organisasional Karyawan. E-Jurnal Manajemen. 8(6), 3730-3755.

Ghozali, Iman. (2011). Aplikasi Analisis Multivariate Dengan Program SPSS. Semarang: Badan Penerbit Universitas Dipenogoro.

Giauque, D., (2014). Attitudes Toward Organizational Change Among Public Middle Managers. Public Personnel Managemen. 44(1), 70-98.

Hamid, F., Sudibya, A. \& Rahyuda, G. (2017). Pengaruh Kepuasan Kerja Dan Komitmen Organisasional Terhadap Sikap Pegawai Mengenai Perubahan Di 
Balai Diklat Industri Kementerian Perindustrian Republik Indonesia. EJurnal Ekonomi dan Bisnis Universitas Udayana. 6(4), 1481-1512.

Herjany, E., \& Bernarto, I. (2018). Pengaruh Lingkungan Kerja, Kepuasan Kerja, dan Stres Kerja Terhadap Komitmen Organisasi Guru TK dan SD pada Sekolah X di Jakarta Barat. Jurnal Manajemen Indonesia. 18(2), 154-164.

Iriana, P., Lilis W., Inon Listyorini. 2004. Pengaruh Faktor Job Insecurity, Kepuasan Kerja, dan Komitmen Organisasi Terhadap Turnover Intention Akuntan Pendidik. 11, 284-296.

Kekesi, Elias Kodjo, \& Collins Badu Agyemang. (2014). Perceived Job Insecurity and Psychological Distress: The Moderating Role Of Work Values. International Journal of Management, Economics and Social Sciences, 3(1), $18-35$.

Khoiroh, N., Bukit, B., Adisetiawan, R (2018) Pengaruh Gaya Kepemimpinan dan Budaya Organisasi terhadap Komitmen Organisasi dalam Meningkatkan Kinerja Pegawai pada Badan Perencanaan Pembangunan Daerah (BAPPEDA) Kabupaten Batang Hari. J-MAS (Jurnal Manajemen dan Sains), 4(1), 197-204.

Kretner \& Kinichi. (2014). Organization Behavior Edisi Sembilan. Jakarta: Salemba Empat.

Kurniawati, I. G. A. N. P., \& Sariyathi, N. K. (2015) Pengaruh Gaya Kepemimpinan Transformasional, Budaya Organisasi, Program K3 Terhadap Kepuasan Kerja Karyawan. E-jurnal Manajemen Unud, 4(9),2544-2561.

Lok, Peter and Crawford, John. (2004). The Effect of Organizational Culture and Leadership Style on Job Satisfaction and Organizational Commitment. The Journal of management Development, 23, 321-337.

Mayer, J. P \& J., Natalie Allen. (1991). A Three Component Conceptualization of Organizational Commitment. Human Resource Management Review, 1(1), 61-89.

Nadhiroh, U (2019) Pengaruh Motivasi Dan Kepuasan Kerja Terhadap Kinerja Karyawan Dengan Budaya Organisasi Sebagai Variabel Moderating Pada Koperta Langgeng Mulyo Ngancar Kediri. 61-77.

Nofriansyah., F. (2016). Hubungan Komitmen Organisasi Dengan Disiplin Kerja Pada Karyawan Indonesia Eximbank. Jurnal Psikologi. 1-9

Pangat, O. P. A., (2013) Analisis Pengaruh Job Insecurity Terhadap Kepuasan Kerja dan Komitmen Organisasional Serta Dampaknya Terhadap Kinerja Karyawan Outsourcing PT. Upaya Kelola Profitama. (2), 164-168 
Priyatno, D. (2012). Cara Kiat Analisis Data dengan SPSS 20. Edisi Kesatu. Yogyakarta: ANDI.

Purnamasari, S., \& Sriathi., A.A.A. (2018). Pengaruh Budaya Organisasi, Gaya kepemimpinan Transformasional, dan Motifasi Karyawan Terhadap Komitmen Organisasional di PT. Ganesha Emas Dwipa cabang Gianyar. Skripsi. Universitas Udayana.

Putra, S., \& Sriathi. A.A.A. (2019). Pengaruh Lingkungan Kerja, Stres Kerja Dan Kompensasi Terhadap Loyalitas Karyawan. E-Jurnal Manajemen Unud, $8(2), 7746-7774$.

Rahmi, A., \& Mulyadi. (2018). Pengaruh Keterlibatan Karyawan, Budaya Organisasi dan Kepemimpinan Transformasional terhadap Komitmen Organisasional Karyawan pada PT. PLN Banda Aceh. 6(1) 68-76.

Reskantika. R., Paminto, A., \& Ulfah. Y. (2019). Pengaruh gaya kepemimpinan dan budaya organisasi serta motivasi terhadap kepuasan kerja dan komitmen organisasi. Jurnal Manajemen. 11(2), 195-202.

Ridho, Syarifur. (2017). Analisis Pengaruh Job Insecurity Dengan Kepuasan Kerja Dan Komitmen Organisasi Sebagai Variabel Intervening Terhadap Intensi Turnover. Jurnal Ilmiah AMK Labuhan Batu, 6(1) 73-81.

Robbins, Stephen P.,Timothy A. Judge. (2013). Organizational Behavior 15th ed. New jersey : Prentice Hall Publishing.

Sandi, M. F. (2014). Analisis Pengaruh kompensasi dan Job Insecurity Terhadap Turnover Intention. Skripsi. Fakultas Ekonomi Dan Bisnis Universitas Diponogoro.

Sanhaji, A., B. E. S., \& Suharto. (2016). Pengaruh Keadilan Organisasi dan Budaya Organisasi Terhadap Perilaku Kewargaan Organisasi Melalui Komitmen Organisasi dan Kepuasan Kerja. Jurnal Pendidikan, 1(5), 917-926.

Saputra, A. \& Andri, S. (2017). Pengaruh Lingkungan Kerja dan Komitmen Organisasi Terhadap Kepuasan Kerja Karyawan (Studi Kasus pada Hotel Ratu Mayang Garden Pekanbaru). JOM FISIP. 4(2) 1-15.

Sedarmayanti. (2009). Sumber Daya Manusia dan Produktivitas Kerja. Bandung: CV Mandar Maju.

Septiari, K., \& Ardana., K. (2016). Pengaruh Job Insecurity Dan Stres Kerja Terhadap Turnovaner Intention Karyawan Pada Hotel Asana Agung Putra Bali. E-Jurnal Manajemen Unud, 5(10), 6429-6456. 
Subagyo, A. (2014). Pengaruh Lingkungan Kerja dan Self Efficacy terhadap Komitmen Organisasional Dosen Politeknik Negeri Semarang. Jurnal Polnes, 10(3), 74-81.

Sugiyono. (2018). Metode Penelitian Kuantitatif, Kualitatif, $R$ dan D, Edisi ke-27. Bandung: Alfabeta.

Suhartini. Y. (2018). Analisis Dimensi Komitmen Organisasional Yang Mempengaruhi Organizational Citizenship Behavior Karyawan Pt. Kai Daop Vi Yogyakarta. Jurnal Akuntansi \& Manajemen Akmenika. 15(2), 93-108.

Sukrisno, A., \& Ardana I. C. (2014). Etika Bisnis dan Prefesi. Jakarta: Selemba Empat.

Suyana, Utama. (2012). Aplikasi Analisis Kuantitatf, Edisi Keenam. Denpasar: Fakultas Ekonomi dan Bisnis Universitas Udayana.

Sverke, M., J. Hellgren., K. Naswall. (2002). No security: A meta-analysis and review of job insecurity and its consequences. Journal of Occupational Health psychology, 7(3): 242-264.

Tanuwibowo, J.C., \& Sutanto. E.M. (2014). Hubungan Budaya Organisasi dan Komitmen Organisasional pada Kinerja Karyawan. Trikonomika. 13(2), 136144.

Wibawa, I. W. S., \& Putra. M. S. (2018). Pengaruh Budaya Organisasi Terhadap Komitmen Organisasinal Dimediasi Kepuasan kerja. E-Jurnal Manajemen Unud. 7(6), 3027-3058.

Widodo. (2014). Influence of Leadership And Work Environment To Job Satisfaction And Impact To Employee Performance (Study On Industrial Manufacture In West Java). Journal of Economics and Sustainable Development, 5(26) 62-66.

Wirawan. (2007). Budaya Organisasi dan Iklim Organisasi Jakarta: Salemba Empat.

Yasmin, E. (2011) Pengaruh Job Insecurity Terhadap Komitmen Organisasional Yang Dimediasi Oleh Kepuasan Kerja Pada Karyawan Outsource PT. Asia Outsourcing Services yang ditempatkan di PT. X. Tesis Universitas Gadjah Mada. 